\title{
ПРОБЛЕМЫ ПРАВОВОЙ КВАЛИФИКАЦИИ ДЕРИВАТИВНОГО ОБЯЗАТЕЛЬСТВА
}

Аннотация: В статье рассмотрены особенности правовой квалификации деривативных обязательств, вытекающих из сделок с деривативами по европейскому законодательству или производными финансовыми инструментами - по российскому. Статья доказывает, что деривативный договор представляет собой непоименованный предпринимательский договор sиі generis, заключаемый с целью получения прибыли или хеджирования предпринимательских рисков, цена которого зависит от размера цены базового актива на реальном рынке. В отличие от меновых договоров, деривативный договор не обеспечивает право сторон договора на гарантированное получение встречного предоставления или его эквивалентно-возмездный характер. Неопределенность получения встречного предоставления позволяет классифицировать деривативный договор в качестве особой разновидности алеаторных договоров, отличных от игр и пари. Проведены исследования с использованием сравнительно-правового и формально-юридического методов. Сравнению были подвергнуты правовые системы России и европейских стран в области законодательства о деривативах, при этом для поиска истины были проанализированы количественные и качественные стороны объекта, теоретические и эмпирические его характеристики. В теории права все гражданскоправовые договоры подразделяются на имущественные и организационные. Право на заключение договора имущественным не является, поскольку объектом данного права являются действия по заключению договора, а не имущество. Неимущественное право нельзя приобрести за определенную цену, поэтому вызывает сомнения правомерность определения опционного договора (опциона) как договора о возмездном предоставлении права заключить договор.

Ключевые слова: дериватив, сделка на разничу, рынок ценных бумаг, опцион, фьючерсный договор, форвардный договор, организационные торги, закон о бирже, договор sui generis, pactum in contrahendo.

DOI: 10.7256/1994-1471.2014.6.11530

$\mathrm{O}$ сновным объектом изучения в договорном праве, в части деривативов, рассматриваемых по европейскому законодательству или производных финансовых инструментов, по российскому, является характер обязательств по деривативным договорам и их правовая природа. По сути, сделки по деривативным договорам не имеют четкой регламентации ни в Гражданском кодексе Российской Федерации, ни в специализированных федеральных законах, таких как Закон «0 рынке ценных бумаг» ${ }^{1}$ или Закон «Об организационных торгах»². Лишь утративший свою силу с

\footnotetext{
Федеральный закон от 22.04.1996 № 39-Ф3 (ред. от 28.12.2013) «О рынке ценных бумаг» // СПС КонсультантПлюс.

Федеральный закон от 21.11.2011 № 325-Ф3 (ред. от 21.12.2013) «Об организованных торгах» // СПС КонсультантПлюс.
}

1 января 2014 года Закон РФ «0 товарных биржах и биржевой торговле» ${ }^{3}$ описывал четкие критерии деривативных инструментов, в частности опциона и фьючерса.

Деривативный договор представляет собой непоименованный предпринимательский договор sui generis, заключаемый с целью получения прибыли или хеджирования предпринимательских рисков, цена которого зависит от размера цены базового актива на реальном рынке. Как уже указывалось, в отличие от меновых договоров, деривативный договор не обеспечивает право сторон договора на гарантированное получение встречного предоставления или его эквивалентно-возмездный характер. Неопределенность получения

\footnotetext{
Закон РФ от 20.02.1992 №2383-1 (ред. от 23.07.2013) «О товарных биржах и биржевой торговле» // СПС КонсультантПлюс.
}

(C) Греков Максим Николаевич

* Аспирант кафедры предпринимательского права, Московский государственный юридический университет имени О.Е. Кутафина (МГЮА)

[9986118@mail.ru]

123317, Россия, г. Москва, Пресненская наб., д. 10С, ИК КИТ ТРАСТ (а/я 36). 
встречного предоставления позволяет классифицировать деривативный договор в качестве особой разновидности алеаторных ${ }^{4}$ договоров, отличных от игр и пари.

В теории права все гражданско-правовые договоры подразделяются на имущественные и организационные. К имущественным относятся все договоры, непосредственно оформляющие акты товарообмена их участников и направленные на передачу или получение имущества (материальных и иных благ). Организационные договоры направлены не на товарообмен, а на его организацию, т.е. на установление взаимосвязей участников будущего товарообмена 5 . Они подразделяются на предварительные, генеральные и многосторонние договоры. В силу предварительного договора его стороны обязуются заключить в будущем основной (имущественный) договор на условиях, установленных предварительным договором (п. 1 ст. 429 ГК) ${ }^{6}$. Такой договор - pactum in contrahendo - был известен еще римскому праву. В дореволюционном российском праве его главной разновидностью был договор запродажи, по которому стороны обязывались в определенный ими срок заключить договор купли-продажи вещи, которой пока нет у продавца (например, будущего урожая) или в отношении которой продавец пока не имеет права собственности (например находящейся в составе перешедшего к нему недавно открывшегося наследства), либо вещи, временно обремененной правами иных лиц (в частности, находящейся в залоге) ${ }^{7}$. Действующее законодательство теперь непосредственно допускает заключение договора куплипродажи в отношении товара, который только будет создан или приобретен продавцом в будущем (п. 2 ст. 455 ГК), в связи с чем необходимость в традиционном договоре запродажи отпала. Однако при организации длительных (иногда многолетних) договорных взаимосвязей участников гражданского, прежде всего предпринимательского оборота, например, по систематическим поставкам крупных партий товара на определенных ими конкретных

4 Иванова Е.В. Договорные формы деривативов: некоторые аспекты правового регулирования // Закон. 2007. № 2. C. $125-135$.

Шевченко О.М. Правовое регулирование организованного рынка: анализ новаций российского законодательства // Бизнес и право за рубежом. 2012. Вып. 2. C. 66-68.

6 Гражданский кодекс Российской Федерации (часть первая) от 30.11.1994 № 51-Ф3 (ред. от 02.11.2013), далее по тексту ГК, Кодекс // СПС КонсультантПлюс.

Подузова Е.Б. Некоторые виды организационного договора в гражданском праве // Юрист. 2013. № 6. условиях, заключение ими предварительных договоров становится весьма полезным и целесообразным. Правовой особенностью порождаемого деривативным договором деривативного обязательства является особый порядок его исполнения, который зависит от колебания стоимости базового актива в будущем и неизвестен сторонам на момент заключения договора ${ }^{8}$.

В частности, цена на базовый актив, сложившаяся к моменту исполнения обязательства, определяет:

- $\quad$ размер денежного обязательства (расчетный форвард, фьючерс);

- должника и кредитора в обязательстве (расчетный форвард и фьючерс);

- $\quad$ выбор способа исполнения (опцион).

В литературе существует точка зрения, согласно которой пари характеризуют как сделку, права и обязанности в которой наступают в зависимости от случая, т.е. как рисковые, или алеаторные, сделки ${ }^{9}$. С одной стороны, как при пари, так и при расчетных деривативах права и обязанности возникают при наступлении определенного условия, т.е. эти сделки являются условными. На расчетные деривативы, таким образом, распространяются нормы ст. 157 ГК об условных сделках. Теоретически это возможно, но, по мнению автора, утверждение, что расчетный дериватив одновременно является как рисковой, так и условной сделкой, явно приведет к противоречию и не позволит их разграничить. Нельзя отождествлять алеаторные и условные сделки, так как существуют принципиальные различия между меновыми сделками, совершенными под условием, и алеаторными. Конечно, можно согласиться с точкой зрения М.И. Брагинского ${ }^{10}$, который считает, что алеаторные сделки есть разновидность условных. Но только в том случае, если мы имеем в виду условные сделки в широком смысле этого слова. Ведь хотя рисковые сделки тоже заключены под условием, оно имеет несколько иное значение. Совершение деривативной сделки означает, что каждая из сторон получает имущественное право - право на получение потенциальной вариационной (или эквивалентной) маржи в случае, если не-

8 Гражданское право: В 4 т. Обязательственное право (том 3) /под ред. Е.А. Суханова. Волтерс Клувер, 2008 (3-е издание, переработанное и дополненное).

9 Иванова Е.В. Деривативы. Форвард, фьючерс, опцион, своп. Экономико-правовая квалификация. М.: Ось89, 2007. С. 213.

10 Договорноеправо Брагинский М.И., Витрянский В.В. Книга пятая. Том 2. Договоры о банковском вкладе, банковском счете; банковские расчеты. Конкурс, договоры об играх и пари. М., Проспект-80, 1998. 
кая цена единицы базисного актива в установленный момент времени окажется выше или ниже ее цены, закрепленной при совершении деривативной сделки.

Согласно ст. 429 ГК РФ предварительным является договор, по которому стороны обязуются заключить в определенный срок основной договор о передаче имущества, выполнении работ или оказании услуг на условиях, предусмотренных предварительным договором. В предварительном договоре должны быть согласованы все существенные условия основного договора. Однако, как указывается в судебной практике, в том случае, когда в предварительном договоре предусмотрено, что условие о цене будет определено сторонами в основном договоре, такая запись должна расцениваться арбитражным судом как достижение согласия сторон о включении в основной договор данного условия ${ }^{11}$. С представленной позицией трудно согласиться. В силу п. 1 ст. 429 ГК РФ по предварительному договору стороны обязуются заключить в будущем договор на условиях, предусмотренных предварительным договором. Следовательно, именно условия, согласованные в предварительном договоре, будут включены в основной договор. Иначе возникает вопрос, как возможно заключить основной договор на условиях, предусмотренных в предварительном, если эти условия существенными условиями основного договора не являются, а лишь позволяют установить существенные условия основного договора. Представляется, ответ на данный вопрос должен быть отрицательным. Полагаю, что в самом предварительном договоре должны быть определены однозначным образом существенные условия основного договора. В Концепции развития гражданского законодательства Российской Федерации (п. 7.6 раздела V) ${ }^{12}$ и в проекте Закона о внесении изменений в Гражданский кодекс РФ (п. 3 ст. 429) предлагалось сократить перечень существенных условий предварительного договора, оставив только условие о предмете и те условия, относительно которых, по заявлению одной из сторон, должно быть достигнуто соглашение. Данное

11 Информационное письмо Президиума Высшего Арбитражного Суда Российской Федерации от 5 мая 1997года № 14 «Обзор практики разрешения споров, связанных с заключением, изменением и расторжением договоров» // Вестник Высшего Арбитражного Суда Российской Федерации. 1997. № 7.

12 Концепция развития гражданского законодательства РФ. Одобрена решением Совета при Президенте Российской Федерации по кодификации и совершенствованию гражданского законодательства от 7 октября 2009 года // Вестник Высшего Арбитражного Суда Российской Федерации. 2009. № 11. предложение нашло свою поддержку в юридической литературе ${ }^{13}$.

Сделки на разницу являются алеаторными договорами, содержание которых состоит в уплате денежной суммы. Ее размер вычисляется исходя из дохода или убытка, который мог бы быть получен по срочной сделке, предусматривающей поставку товаров или ценных бумаг, после ликвидации обязательства по поставке или принятию. Для признания сделки игрой на разницу в качестве таковой не требуется, чтобы в договоре непосредственно оговаривалось исполнение в денежной форме путем уплаты ценовой разницы (явная сделка на разницу). Достаточно, чтобы присутствовала подлинная воля сторон на ее уплату, пусть и в скрытой форме (скрытая сделка на разницу). Результатом волеизъявления может быть молчаливое согласие сторон на уплату разницы. Поэтому довольно часто сделками на разницу признаются соглашения, которые замаскированы под поставочные сделки, но стороны которых в действительности договорились об исполнении путем уплаты ценовой разницы. Согласно общему правилу о притворных сделках при их правовой оценке следует исходить из того, какую (скрытую) сделку действительно намеревались совершить стороны, а не из того, какая сделка использовалась в качестве прикрытия. Это является правильным и в том случае, когда сделка на разницу прикрывается не одной поставочной сделкой, а двумя заранее оговоренными мнимыми, зеркальными по отношению друг к другу поставочными сделками с разными сроками исполнения и внешне не связанными друг с другом, т.е. имеет место основная сделка и ликвидационная сделка.

Вследствие того, что платежи по деривативам стохастически обусловлены и в момент заключения договора размер обязательств по деривативам не определён, терминологически их можно классифицировать как «долговые обязательства, имеющие денежное выражение», отличая от долговых обязательств по уплате определенной денежной суммы. Это, правда, не приводит к каким-либо новым правовым последствиям ${ }^{14}$. Для такого рода платежных обязательств причитающаяся к выплате денежная сумма устанавливается не в

13 Шанаурина Ю.В. Институт предварительного договора в гражданском праве России: дисс. ... канд. юрид. наук. Тюмень, 2006. С. 105-106; Садиков О.Н. Предварительный договор и его условия // Хозяйство и право. 2011. № 3. С. 11.

Греков М.Н. Правовой анализ российского законодательства о ликвидационном неттинге // Предпринимательское право, 2012, № 4. 
момент заключения договора, а должна быть определена позже расчётным путем ${ }^{15}$.

Таким образом, определение размера денежной суммы происходит не при возникновении долгового обязательства, а позднее, в установленный момент времени или в момент исполнения, ведь ее размер зависит от постоянно изменяющихся фактических параметров, которые могут быть заданы соглашением сторон, правовой природой или целью обязательства. Главное отличие денежных обязательств по деривативам от иных договорных обязательств, имеющих денежное выражение, как, например, обязательств по договору купли-продажи с индексацией цены, состоит в его вычисляемости в любой момент времени, в том числе непосредственно перед исполнением.

Вместе с тем Г. Райнер предлагает узкую трактовку деривативов, которая направлена на выделение их в особый класс отношений и выявление отличий от других срочных сделок. Так, в трактовке Г. Райнера деривативы - это взаимные договоры, цена которых является производной от некоторой лежащей в их основе величины (базисной стоимости, базиса), зависящей от рыночных котировок ${ }^{16}$. С этой точки зрения деривативами следует считать только те инструменты, которые связаны не с физической поставкой товара, а с хеджированием ценовых рисков без его поставки. При этом Г. Райнер указывает, что поставочный форвард не может считаться деривативом ${ }^{17}$. Таким образом, данный специализированный подход направлен на выделение деривативов из общего понятия биржевой срочной сделки, а с другой стороны - на их отграничение от рисковых сделок на разницу. Подобная дифференциация отношений видится вполне обоснованной, поскольку цели соответствующих сделок существенно различаются. Если в одном случае целью совершения сделки становится приобретение товара на определенных условиях, то в другом - хеджирование цены на товар без стремления его приобрести. Кроме того, отличия деривативов от указанных инструментов касаются также их правовой конструкции, порядка совершения и т.д. Таким образом, деривативами может признаваться определенная совокупность производных финансовых инструментов, которая соответствует ряду признаков. С этой особенностью связано так-

15 Иванова Е.В. Расчетный форвардный контракт как срочная сделка. М.: Волтерс Клувер, 2004.

16 Райнер Г. Внебиржевые срочные сделки при банкротстве: сравнительно-правовое исследование актуальных инициатив по реформированию российского законодательства // СПС КонсультантПлюс.

17 Там же. же свойство воспроизводимости деривативов, которое состоит в том, что поток платежей по деривативам в каждый момент времени может быть воспроизведен посредством инвестиций на наличном рынке базисного актива.

Стохастический или алеаторный характер сделок с производными финансовыми инструментами, который проявляется в том, что прибыльность или убыточность данных отношений для их участников зависит от случая. Как указывает Г. Райнер, в случае так называемого алеаторного договора распределение рисков заходит так далеко, что оно распространяется на договорное равновесие как таковое. Алеаторный договор заключается ради самой неопределенности. Ее утрата при алеаторных сделках означает, что взаимное исполнение теряет смысл, по крайней мере для одной из сторон. От алеаторности производных инструментов следует отличать рисковый характер сделок на разницу, целью которых является риск ради риска, т.е. представляющих собой в чистом виде игру спекулянтов на бирже. В связи с этим применительно к деривативам в узком понимании предлагается говорить об их стохастической обусловленности ${ }^{18}$.

В судебной практике деривативы, заключенные в форме срочных сделок с товарами, драгоценными металлами и ценными бумагами, без колебаний признаются сделками на разницу. Благодаря расширительному толкованию понятия товара валюта однозначно включается в него. Договоры на основе расчетных величин, привязанных к цене акций, не приводя никаких обоснований, считают сделками на разницу. Остается открытым вопрос, основывается ли такой вывод на расширительном толковании понятия ценной бумаги или на законодательной аналогии.

При заключении двусторонне обязывающего договора, предметом которого является заменимое, то есть определяемое родовыми признаками имущество или услуга, всегда существует возможность экономически «нейтрализовать» собственное обязательство или право требования. Для этого необходимо заключить обратную сделку с аналогичными условиями и с тем же контрагентом или третьим лицом. В результате второй сделки участник рынка занимает такую же позицию, что и его контрагент по первой сделке. Предложенная стратегия будет практически реализуемой, когда условия сделок стандартизированы и существует их ликвидный рынок. Между тем в случае деривативов существование такого рынка (а именно ликвидного срочного рынка)

18 Райнер Г. Указ. соч. С. 14. 
для ликвидации позиции не требуется. Согласно определению потоки платежей, порождаемые этими инструментами, воспроизводятся на наличном рынке, и это справедливо для обеих сторон договора, поэтому занимаемая при заключении договора позиция в любой момент времени может быть нейтрализована (ликвидирована, застрахована, хеджирована) посредством заключения обратной сделки на кассовом рынке.

С точки зрения каузальной модели, решающее значение для действительности алеаторных договоров имеет тот факт, что как таковые стохастически обусловленные требования и обязательства уже при заключении договора имеют для сторон договора некоторую субъективную ценность независимо от развития ситуации на рынке базисного актива вплоть до момента исполнения договора. Эта имущественная ценность является реальной, если позиция в любой момент времени имеет некоторую объективную рыночную стоимость и сторона договора принципиально в состоянии, используя свои личные знания и опыт, получить эту рыночную стоимость или использовать ее иным образом.

В принципе возможны две различные ситуации, допускающие получение в любой момент времени рыночной стоимости договорной позиции: существование ликвидного вторичного рынка, на котором соответствующая рыночная позиция может быть продана, и ликвидация позиции путем заключения другой, обратной сделки на наличном или срочном рынке.

К примеру, один из видов опционных договоров предусматривает обязанность стороны договора на условиях, определенных при его заключении, в случае предъявления требования другой стороной заключить с ней или с лицом (лицами), в интересах которых был заключен опционный договор, договор куплипродажи ценных бумаг, договор купли-продажи иностранной валюты или договор поставки товара, либо обязанность стороны договора в случае предъявления требования другой стороной заключить договор, являющийся производным финансовым инструментом и составляющий базисный (базовый) актив. Coгласно одному из мнений опционный договор является возмездным, односторонним предварительным договором ${ }^{19}$. Иные авторы полагают, что опционный договор имеет ряд отличий от предварительного договора и может быть отнесен к не поименованным в Гражданском кодексе РФ видам договоров. Право требова-

\footnotetext{
19 Меньшенин П.А. Опционный договор на заключение срочной сделки // Право и экономика. 2008. № 5. C. 24.
}

ния заключить договор по опционному контракту носит односторонний характер, по этому договору обязанная сторона получает вознаграждение ${ }^{20}$. Как представляется, данный вид опционного договора включает организующие элементы, поскольку на его основании заключается иной договор. По опционному договору только одна сторона несет обязанность заключить договор в будущем, другая сторона лишь имеет право требовать заключения договора.

Таким образом, право на заключение договора имущественным не является, поскольку объектом данного права являются действия по заключению договора, а не имущество. Неимущественное право нельзя приобрести за определенную цену, поэтому вызывает сомнения правомерность определения опционного договора (опциона) как договора о возмездном предоставлении права заключить договор. Ряд иных положений ст. $429.2^{21}$ свидетельствует о сходстве опционного договора с предварительным договором. На данный момент правовая природа опционного договора (опциона) не ясна. Остается открытым вопрос о сфере применения такого опционного договора и о соотношении норм ГК РФ об опционном договоре и норм об опционных договорах в иных нормативно-правовых актах.

Рассмотрим природу деривативного договора на примере расчетного форвардного договора. Денежное обязательство из расчетного форвардного договора возникает не при заключении договора купли-продажи форвардного договора (обязательства принять и передать товар), а в момент выплаты вариационной маржи. Расчетный форвардный контракт по своей правовой природе не имеет ничего общего с играми и пари. При заключении такой сделки выигрыш или проигрыш сторон поставлен в зависимость не от факта наступления событий, а от стечения обстоятельств и от поведения участников. Так, стороны договора, например, могут реально воздействовать на цену погашения расчетного форвардного договора посредством заключения сделок на реальных рынках: изменившаяся цена на реальный товар будет служить базисом расчета в расчетном контракте. Такое поведение сторон

20 Жуков Д.А. Правовое регулирование срочных сделок на фондовом рынке: автореф. дисс. ... канд. юрид. наук. М., 2006. С. 8; Иванова Е.В. Деривативы. Форвард, фьючерс, опцион, своп. Экономико-правовая квалификация. М.: Ось-89, 2007. С. 213.

21 Проект Федерального закона №47538-6 «О внесении изменений в части первую, вторую, третью и четвертую Гражданского кодекса Российской Федерации, а также в отдельные законодательные акты Российской Федерации» (ред., принятая ГД ФС РФ в І чтении 27.04.2012). 
будет считаться добросовестным и оправданным, в отличие, например, от использования участниками отношений инсайдерской информации ${ }^{22}$. Хотя большинство участников этого рынка на исход торгов влияния не оказывают и реально оказать не могут, следует учесть, что гипотетически такие шансы у них все же есть. Крупные же участники финансовых рынков такое влияние оказывают в действительности. Относительно спора о происшествии или не происшествии события следует заметить, что при заключении расчетной форвардной сделки обязательства сторон по выплате вариационной маржи с определенным сроком расчетов еще не возникают, они могут возникнуть в будущем. Однако при определенных условиях (совпадении начальной цены договора и цены его погашения) обязательства сторон могут полностью отсутствовать.

Как было отмечено, условной называется сделка, стороны которой ставят возникновение или прекращение прав и обязанностей в зависимость от какого-то обстоятельства, которое может наступить или не наступить в будущем. В качестве условия могут выступать как события, так и действия граждан и юридических лиц. При этом в качестве условия могут рассматриваться как действия третьих лиц, так и действия самих участников сделки. События и действия, относимые к условиям, должны обладать определенными признаками:

1. В момент совершения сделки ее участникам не должно быть известно, наступит или не наступит в будущем обстоятельство, включенное в сделку в качестве условия.

2. Произвольность установления условия.

3. Условие не должно противоречить закону, основам правопорядка и нравственности.

Таким образом, делаем вывод о том, что деривативный договор на примере расчетного форварда действительно является условной сделкой, что ни в коей мере не должно влиять на его охраноспособность. В противном случае, если ссылаться на условность расчетного форвардного договора как основания для отказа в его судебной защите, следующим логичным и неизбежным шагом будет отказ в судебной защите любым обязательствам, в которых, например, момент возникновения прав и обязанностей или перехода права собственности поставлен в зависимость от наступления некоторого события, подпадающего под приведенные выше признаки. Соответственно, можно сделать вывод, что условность расчетного форварда не является даже косвенным основанием

22 Шеленкова Н. Б. Биржевые правонарушения // Законодательство. 1998. № 2. для его квалификации как пари и, соответственно, отказа в его судебной защите. Обратимся к другим особенностям расчетного форварда, которые зачастую представляются в качестве оснований подобной квалификации. Выгода, приобретаемая стороной расчетного форвардного договора, как и выгода, приобретаемая участником пари, всецело зависит от случайного события. Это характерный признак рисковых договоров, к которым Кодекс Наполеона ${ }^{23}$, объединяющий эти договоры в титул XII главы III, относит, помимо игры и пари, договор страхования, морской заем и договор пожизненной ренты (ст. 1964). Термин «рисковый» характеризует договор с точки зрения выраженной в нем воли сторон и не касается существа возникающих у сторон прав и обязанностей, никак не характеризует эти права и обязанности. Поэтому в литературе совершенно справедливо употребляется термин «рисковые сделки», а не «рисковые договоры».

Однако практически любой предпринимательский договор (сделка) носит рисковый характер. Одни из них прямо характеризуются как полностью или частично алеаторные (в частности, договор постоянной ренты с определенными ограничениями, предусмотренными, например, п. 1 ст. 592 ГК РФ), другие являются таковыми по сути, т.к. любой договор поставки может быть не исполнен в силу либо недобросовестности контрагента, либо воздействия непреодолимой силы, что повлечет убытки одной из сторон. В таком контексте представляется логичным либо отказать в судебной защите всем предпринимательским договорам, либо не ссылаться на рисковый характер расчетного форвардного договора как основания для отказа в предоставлении такой защиты. Из легального определения видно, что производные финансовые инструменты являются разновидностью гражданско-правовых сделок ${ }^{24}$. Эти сделки, так же как и любые другие, направлены на установление, изменение или прекращение гражданских прав или обязанностей (ст. 153 ГК РФ) и представляют собой соглашение, по которому одна сторона обязуется передать другой стороне в собственность товар, а другая, в свою очередь, заплатить за него

\footnotetext{
23 Кодекс Наполеона (фр. Code Napoléon), также Гражданский кодекс французов (фр. Code Civil des Français) масштабный кодекс гражданского права Франции, разработанный группой юристов в начале XIX в. во время правления первого консула Французской республики (затем императора) Наполеона Бонапарта и действующий, с изменениями, до настоящих дней. // http:// ru.wikipedia.org/wiki/

24 Мильдзихов О.О. Производный финансовый инструмент - новелла российского гражданского законодательства // Общество и право. 2011. № 2.
} 
заранее обусловленную цену. По своей правовой природе срочные сделки являются куплейпродажей или поставкой. Вместе с тем биржевые сделки имеют особенности, связанные с субъектами, заключающими такие сделки, их объектом и способом заключения ${ }^{25}$.

Вместе с тем представляется целесообразным отказ законодателя от термина «срочные сделки» при выделении биржевых сделок с отсроченным сроком поставки из остальной массы гражданско-правовых сделок, так как смысловое содержание понятия «срочные сделки» намного объемнее, чем то, что вкладывается в это понятие при обозначении биржевых сделок. Ведь в понятие «срочные сделки» входят не только биржевые сделки, но и все гражданско-правовые сделки, где указывается срок, с которого у сторон возникают права и обязанности, срок исполнения и срок прекращения действия сделки. Вместо термина «срочные сделки» представляется целесообразным использовать термины «дериватив» или «производный инструмент», которые стали привычными в биржевой терминологии и употребляются специалистами в области биржевой торговли.

Под деривативом следует понимать биржевой договор с отсроченным сроком исполнения, стоимость которого зависит от стоимости лежащего в основе этого контракта биржевого актива (базисного актива). Такое определение подчеркивает особенность этого рода биржевых сделок. Во-первых, это определение отграничивает деривативы от кассовых биржевых сделок; во-вторых, подчеркивает зависимый характер дериватива от лежащего в его основе биржевого актива, т.е. является производной от базисного актива, лежащего в основе контракта.

Так, в мировой практике под деривативом понимают финансовые инструменты, ценность которых проистекает из колебания цен на соответствующие активы, такие как финансовые продукты или статистические индикаторы ${ }^{26}$. Из содержания определения производных финансовых инструментов видно, что оно включает в себя все то многообразие совершаемых на биржевых и внебиржевых торгах сделок с отсроченным сроком исполнения, которые в мировой практике могут обозначаться как

25 Шершеневич Г.Ф. Курс торгового права. СПб., 1908. T. 2. -335 c.

26 Кидуэлл Д.С., Петерсон Р.Л., Блэкуэлл Д.У. Финансовые институты, рынки и деньги: пер. с англ. СПб. М.; Харьков; Минск, 2000. - 752 с.; Ротко С.В., Тимошенко Д.А. Производные финансовые инструменты сегодня: ситуация, требующая законодательного решения // Налоги и финансовое право. 2008. № 1. С. 309-313. деривативы, биржевые срочные сделки и т.д. Несмотря на вышеуказанные нововведения, в законодательстве сохраняется терминологическая путаница относительно обозначения и наименования рынка срочных сделок.

Понятие производный финансовый инструмент определяется через понятие финансовый инструмент, под которым в юридической литературе и в системе российского права понимается ценная бумага либо иной документ, удостоверяющий право владельца данного документа на то или иное имущество, имущественные права. Если следовать логике законодателя, то получается, что производным финансовым инструментом по существующему определению можно считать любой поставочный фьючерсный договор, базисным активом которого является реальный биржевой товар, например нефть, зерно, который нельзя отнести к ценным бумагам (финансовым инструментам). В связи с этим для обозначения огромного массива сделок с отсроченным сроком исполнения предпочтительнее было бы использовать термин «дериватив», а не «производный финансовый инструмент». Кроме того, следует отметить, что в деловой практике биржевых и внебиржевых торгов термин «дериватив» получил наибольшее распространение.

Таким образом, указание на то, что финансовый инструмент может представлять собой лишь ценную бумагу или производный финансовый инструмент, является юридически некорректным. Некоторые авторы полагают, что производные финансовые инструменты имеют все шансы качественно перейти в производные ценные бумаги ${ }^{27}$. Так, например, Л. Кузнецова отмечает, что «фьючерс представляет собой контракт на срочную сделку, превращенный в ценную бумагу и покупаемый/ продаваемый на фьючерсной бирже» ${ }^{28}$.

Проанализируем российское законодательство на предмет соотношения производного финансового инструмента и ценной бумаги. Согласно ст. 143 ГК РФ к ценным бумагам могут быть отнесены бумаги, которые, во-первых, прямо названы таковыми; во-вторых, отнесены к ценным бумагам законами о ценных бумагах или в установленном ими порядке. В перечень ценных бумаг, закрепленный ст. 143 ГК РФ, разновидности производных финансовых инструментов не включены. В соответст-

27 Ротко С.В., Тимошенко Д.А. Производные финансо-
вые инструменты сегодня: ситуация, требующая зако-
нодательного решения // Налоги и финансовое право. нодательного решени

28 Кузнецова Л. Деривативы в экономическом пространстве России: Вопросы терминологии // РЦБ. 2006. № 7. C. 37-40. 
вии со ст. 2 Ф3 «0 рынке ценных бумаг», эмиссионная ценная бумага - любая ценная бумага, в том числе бездокументарная, которая характеризуется одновременно следующими признаками:

а) закрепляет совокупность имущественных и неимущественных прав, подлежащих удостоверению, уступке и безусловному осуществлению с соблюдением установленных законом формы и порядка (в данном случае закон противоречит ст. 142 ГК РФ, в которой неимущественные права отсутствуют);

б) размещается выпусками;

в) имеет равный объем и сроки осуществления прав внутри одного выпуска вне зависимости от времени приобретения ценной бумаги.

Действительно, совершение, например, расчетного фьючерсного договора означает, что одна из сторон получает имущественное право - право на получение вариационной маржи. Кроме того, наличие совокупности однообразных характеристик каждой фьючерсной сделки может служить достаточным доказательством для признания наличия выпуска ценных бумаг, в рамках которого все ценные бумаги имеют единый срок осуществления прав. Однако при заключении такой сделки невозможно определить, какая из сторон сделки будет уплачивать вариационную маржу, т.е. кто будет должником по сделке. Теоретически возможна также ситуация, когда цена товара в момент исполнения сделки совпадает с ценой товара на момент заключения сделки, и ни одна из сторон не будет иметь права на получение вариационной маржи. Таким образом, в момент заключения невозможно определить ни должника, ни кредитора по этому контракту, а из п. 1. ст. 142 ГК РФ следует, что в ценной бумаге обязательно указание должника. Как было выяснено, сделать это во фьючерсном контракте объективно невозможно. Согласно п. 2 ст. 144 ГК РФ отсутствие в ценной бумаге одного из обязательных реквизитов влечет ее недействительность.

И наконец, абсолютно неприменима третья основополагающая характеристика эмиссионной ценной бумаги, так как каждый фьючерсный договор предоставляет выигравшим участникам разный объем имущественных прав. Поскольку участники конкретного фьючерсного договора самостоятельно фиксируют фьючерсную цену, то и размер вариационной маржи по каждому фьючерсному контракту будет различным. Изложенное приводит к выводу, что производные финансовые инструменты в том виде, в котором они существуют в настоящее время, не относятся к ценным бумагам.
Автором подтвержден довод о том, что деривативное обязательство - правовая связь между сторонами деривативного договора, в соответствии с которым каждая из сторон обязуется перед другой стороной либо заключить договор на поставку базового актива в будущем, либо уплатить денежную сумму, размер которой зависит от размера цен на базовый актив на реальном рынке. Правовой особенностью порождаемого деривативным договором деривативного обязательства является особый порядок его исполнения, который зависит от колебания стоимости базового актива в будущем и неизвестен сторонам на момент заключения договора.

В частности, цена на базовый актив, сложившаяся к моменту исполнения обязательства, определяет:

- $\quad$ размер денежного обязательства (расчетный форвард, фьючерс);

- должника и кредитора в обязательстве (расчетный форвард и фьючерс);

- $\quad$ выбор способа исполнения (опцион).

Правовой особенностью расчетных деривативных обязательств является неопределенность правового положения сторон в обязательстве до наступления срока его исполнения. До наступления указанного срока неизвестно, какая из сторон является должником, а какая кредитором. Указанная правовая особенность позволяет выделить расчетные деривативные обязательства в новую разновидность гражданско-правовых обязательств обязательства с альтернативной ролью субъектов обязательства.

Таким образом, срочные финансовые сделки могут быть разделены на два вида:

1) сделки с переходом права собственности на предмет сделки (поставочные производные финансовые сделки);

2) сделки, исполнение по которым осуществляется исключительно путем выплаты ценовой разницы (расчетные производные финансовые сделки).

В зависимости от вида базового актива, лежащего в основе деривативного договора, будет изменяться и деривативное обязательство, присущее данному виду договоров.

В качестве одного из выводов необходимо отметить, что при классификации деривативных договоров выявляются смежные с играми и пари правовые институты: фьючерсный договор, расчетный форвард, опционный договор, своповое соглашение и т. п., которые обладают схожими чертами и объединяются в термин «деривативы» или «производные финансовые инструменты»». При этом выделяется три основных признака таких сделок: вопервых, момент исполнения договора отстает 
от момента его заключения; во-вторых, цена договора формируется за счет биржевого актива, лежащего в основе договора, в-третьих, договор исполняется не реальной поставкой биржевого товара, а выплатой ценовой разницы между ценой биржевого товара, установленной в договоре, и ценой, сформированной на бирже к моменту исполнения договора.

Существует еще одна проблема, способная породить, а зачастую и порождающая ряд значительных практических проблем. Речь идет о правовой квалификации опционного контракта как гражданско-правового договора. Подобно фьючерсу ряд исследователей признает опцион предварительным договором, при этом односторонним предварительным договором, т.е. одним только правом без корреспондирующей ему обязанности ${ }^{29}$. К примеру, в утратившем силу с 1 января 2014 года Законе о товарных биржах и биржевой торговле ${ }^{30}$, опцион определялся в качестве уступки прав на будущую передачу прав и обязанностей в отношении биржевого товара или контракта на поставку биржевого товара.

В связи с этим передача прав и обязанностей могла означать только право приобретателя опциона по своему выбору заключить контракт на поставку товара или не заключать его. При этом сам опцион вполне можно квалифицировать в качестве односторонней сделки, так как в соответствии со ст. 155 ГК РФ совершение односторонней сделки (в рассматриваемом случае - заключение опционного контракта) создает обязанности для лица, совершившего сделку. Опционная премия, выплачиваемая за право приобретения опциона, является частью договора купли-продажи прав, выплачивается при приобретении опциона и в дальнейшем в его обращении не участвует.

Подводя итог, следует выделить как правовые, так и иные риски, присущие деривативным сделкам. В литературе разброс мнений о проблемах правовой квалификации деривативов и деривативоподобных сделок в качестве сделок на разницу достаточно широк. Исключение составляют лишь обычные договоры покупки или продажи на срок, безоговорочно подпадающие под такую квалификацию. Похожая ситуация складывается применительно к другим базисным активам, помимо товаров и ценных бумаг, например, к процентным ставкам или расчетным единицам, производным от стоимости ценных бумаг. Соответственно в качестве сделок на разницу квалифицируются процентные срочные сделки и сделки на индекс. Первичные и вторичные сделки с опционами, оформленными в виде договоров, всегда рассматриваются как сделки на разницу. Опционы в форме ценной бумаги иногда полностью, иногда лишь частично - в случае, если они предусматривают поставку - исключаются из этой категории.

Проблемами правовой квалификации деривативов являются присущие данным сделкам риски, которые указывают на неопределенность конструкций договоров и неясность относительно получения или размера будущих доходов или убытков, возникающую из-за недостатка информации, субъективного или объективного незнания, когда рациональные решения принимаются на основе неполной или неточной информации (например, экономическое планирование, частные инвестиционные решения, оценка и использование прибыли).

\section{Библиография:}

1. Иванова Е.В. Договорные формы деривативов: некоторые аспекты правового регулирования // Закон. 2007. № 2. С. 125-135.

2. Шевченко О.М. Правовое регулирование организованного рынка: анализ новаций российского законодательства // Бизнес и право за рубежом. 2012. Вып. 2. С. 66-68.

3. Подузова Е.Б. Некоторые виды организационного договора в гражданском праве // Юрист. 2013. № 6 .

4. Иванова Е.В. Деривативы. Форвард, фьючерс, опцион, своп. Экономико-правовая квалификация. М.: Ось-89, 2007.

5. Греков М.Н. Правовой анализ российского законодательства о ликвидационном неттинге // Предпринимательское право. 2012. № 4.

6. Иванова Е.В. Расчетный форвардный контракт как срочная сделка. М.: Волтерс Клувер, 2004.

\footnotetext{
29 Греков М.Н. Правовой анализ российского законодательства о ликвидационном неттинге // Предпринимательское право. 2012. № 4.

30 Закон РФ от 20.02.1992 №2383-1 (ред. от 23.07.2013) «О товарных биржах и биржевой торговле» // СПС КонсультантПлюс.
} 
7. Райнер Г. Внебиржевые срочные сделки при банкротстве: сравнительно-правовое исследование актуальных инициатив по реформированию российского законодательства // СПС КонсультантПлюс, 2013.

8. Шанаурина Ю.В. Институт предварительного договора в гражданском праве России: дисс. ... канд. юрид. наук. Тюмень, 2006. С. 105-106; Садиков О.Н. Предварительный договор и его условия // Хозяйство и право. 2011. № 3. С. 11.

9. Меньшенин П.А. Опционный договор на заключение срочной сделки // Право и экономика. 2008. № 5. C. 24.

10. Жуков Д.А. Правовое регулирование срочных сделок на фондовом рынке: автореф. дисс. ... канд. юрид. наук. М., 2006.

11. Шершеневич Г.Ф. Курс торгового права. СПб., 1908. Т. 2. - 335 с.

12. Кидуэлл Д.С., Петерсон Р.Л., Блэкуэлл Д.У. Финансовые институты, рынки и деньги: пер. с англ. СПб.; М.; Харьков; Минск, 2000. - 752 с.;

13. Ротко С.В., Тимошенко Д.А. Производные финансовые инструменты сегодня: ситуация, требующая законодательного решения // Налоги и финансовое право. 2008. № 1. С. 309-313.

14. Гражданское право: В 4 т. Обязательственное право» (том 3) /под ред. Е.А. Суханова. Волтерс Клувер, 2008.

\section{References:}

1. Ivanova E.V. Dogovornye formy derivativov: nekotorye aspekty pravovogo regulirovaniya // Zakon. 2007. № 2. S. 125-135.

2. Shevchenko O.M. Pravovoe regulirovanie organizovannogo rynka: analiz novatsii rossiiskogo zakonodatel'stva // Biznes i pravo za rubezhom. 2012. Vyp. 2. S. 66-68.

3. Poduzova E.B. Nekotorye vidy organizatsionnogo dogovora v grazhdanskom prave // Yurist. 2013. № 6.

4. Ivanova E.V. Derivativy. Forvard, f'yuchers, optsion, svop. Ekonomiko-pravovaya kvalifikatsiya. M.: Os'-89, 2007.

5. Grekov M.N. Pravovoi analiz rossiiskogo zakonodatel'stva o likvidatsionnom nettinge // Predprinimatel'skoe pravo. 2012. № 4.

6. Ivanova E.V. Raschetnyi forvardnyi kontrakt kak srochnaya sdelka. M.: Volters Kluver, 2004.

7. Rainer G. Vnebirzhevye srochnye sdelki pri bankrotstve: sravnitel'no-pravovoe issledovanie aktual'nykh initsiativ po reformirovaniyu rossiiskogo zakonodatel'stva // SPS «Konsul'tantPlyus», 2013.

8. Shanaurina Yu.V. Institut predvaritel'nogo dogovora v grazhdanskom prave Rossii: diss. ... kand. yurid. nauk. Tyumen', 2006. S. 105-106; Sadikov O.N. Predvaritel'nyi dogovor i ego usloviya // Khozyaistvo i pravo. 2011. № 3. S. 11.

9. Men'shenin P.A. Optsionnyi dogovor na zaklyuchenie srochnoi sdelki // Pravo i ekonomika. 2008. № 5. S. 24.

10. Zhukov D.A. Pravovoe regulirovanie srochnykh sdelok na fondovom rynke: avtoref. diss. ... kand. yurid. nauk. M., 2006.

11. Shershenevich G.F. Kurs torgovogo prava. SPb., 1908. T. 2. - 335 s.

12. Kiduell D.S., Peterson R.L., Blekuell D.U. Finansovye instituty, rynki i den'gi: per. s angl. SPb.; M.; Khar'kov; Minsk, 2000. - 752 s.;

13. Rotko S.V., Timoshenko D.A. Proizvodnye finansovye instrumenty segodnya: situatsiya, trebuyushchaya zakonodatel'nogo resheniya // Nalogi i finansovoe pravo. 2008. № 1. S. 309-313.

14. Grazhdanskoe pravo: V 4 t. Obyazatel'stvennoe pravo» (tom 3) /pod red. E.A. Sukhanova. Volters Kluver, 2008. 